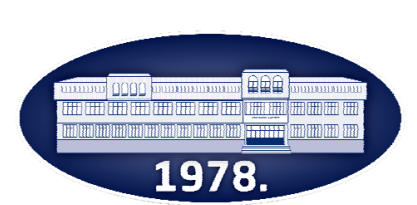

Publisher: Faculty of Agronomy Čačak

\title{
Effect of type and mode of zeolite application on the cigarette filters efficiency and sorption capacity
}

\author{
Vesna Radojičić1*, Sladjana Alagić ${ }^{2}$, Lazar Pejićn ${ }^{1}$, Jovanka Laličić-Petronijević1 \\ 1 University of Belgrade, Faculty of Agriculture, Nemanjina 6, 11080 Belgrade, Serbia \\ 2University of Belgrade, Technical faculty, Vojske Jugoslavije 12, 19210 Bor, Serbia
}

*Corresponding author: mntabacco@agrif.bg.ac.rs

Received 2 June 2020; Accepted 9 November 2020

\begin{abstract}
A B S T R A C T
Filtration is one way of purification of tobacco smoke. The aim of this study was to examine the potential filtration effects of zeolites Y and ZSM-5, with different degree of crystallinity and in two modes of application (as a segment or as a powder added longitudinally with the filter fibers). Zeolites were added in the quantity of $60 \mathrm{mg}$. Degree of filter efficiency and sorption capacity has been determined in regard to several hazardous constituents of mainstream tobacco smoke such as: tar, carbon monoxide and nicotine. Composition of mainstream tobacco smoke was determined by using standard ISO methods. Experimental results showed that both, the type and the mode of the zeolite application affected the efficiency of smoke filtration. Zeolite Y, which was longitudinally applied to the filter, is shown to be the most effective. It was found $58.82 \%$ reduction of nicotine, $66.86 \%$ of tar and $86.24 \%$ of CO. During segmental application of zeolites, the blocking effect was observed.
\end{abstract}

Keywords: mainstream tobacco smoke, filtration, zeolites, longitudinally application, application by segment.

\section{И 3 В О д}

Филтрација је један од начина пречишц́авања дуванског дима. Циљ ове студије био је да се испитају потенцијални ефекти филтрације зеолита Y и ZSM-5, са различитим степеном кристаличности и у два начина примене (као сегмент или као прах који се додаје уздужно у односу на филтер влакна). Зеолити су додати у количини од 60 mg. Степен ефикасности филтра и сорпциона способност утврђени су у односу на неколико опасних састојака главне струје дуванског дима као што су: катран, угљен моноксид и никотин. Састав главне струје дуванског дима одређен је коришц́ењем стандардних ISO метода. Експериментални резултати показали су да и тип и начин примене зеолита утичу на ефикасност филтрације дима. Зеолит Y, који је уздужно нанесен на филтер, показао се најефикаснијим. Установљено је $58,82 \%$ смањења никотина, 66,86\% катрана и 86,24\% СО. Током сегментарне примене зеолита примец́ен је ефекат блокирања.

Кључне речи: главна струја дуванског дима, филтрација, зеолити, уздужна примена, примена по сегментима.

\section{Introduction}

Tobacco smoke is a complex aerosol containing of about 6000 components, which belong to different groups of chemical compounds (Rodgman and Perfetti, 2009). Of the many components of tobacco smoke, each has its own significance in terms of sensory properties and health aspects in regard to active and passive smokers (Fawky, 2004). Many constituents of tobacco smoke are harmful to human health, and some of them are even carcinogenic (Institute of medicine 2001; IARC, 2004). It has been estimated that there are 150 toxic chemical constituents in tobacco smoke (Rodgman and Green, 2003). Nicotine, tar (nicotinefree, dry particulate matter of tobacco smoke-NFDPM) and carbon monoxide (CO) are among those considered highly dangerous (US Federal Trade Commission, 2000).

According to the rules of the World Health Organization (WHO) and the International Committee for Standardization (ISO), the basic objective measure of quality testing of cigarettes which must be declared on the package, are the content of tar, $\mathrm{CO}$ and nicotine in cigarette smoke (WHO, 2000). Tar and nicotine can be found in the particulate phase of tobacco smoke, while $\mathrm{CO}$ is an integral part of the gas phase. The maximum permitted amounts of nicotine $(1 \mathrm{mg} / \mathrm{cig})$, tar and CO $(10 \mathrm{mg} / \mathrm{cig})$ in tobacco smoke are regulated by Tobacco Law of the Republic of Serbia (2019).

With increasing concerns about health problems caused by smoking, both cigarette manufacturers and scientists make joint efforts to reduce the amount of harmful and carcinogenic substances in tobacco smoke (Hoffmann and Hoffmann, 1997). According to numerous published studies, there are different possibilities for purification of tobacco smoke in terms of removing the harmful substances as much as possible (Hoffmann et al., 1980). The simplest and the cheapest way is the selection of tobacco blend composition, more precisely - the optimization of the quantity of certain types of tobacco in a cigarette blend (Djulančić et al., 2013). The others refer to changes of burning conditions (Radojičić et al., 2005; 2006; 2008; 2009a; 2009b; Radojičić and Nikolić 2006; 2007) in a way which provides more complete burning and also to 
the reduction of harmful substances by addition of zeolite into the tobacco mixture.

Filtration (the retention of part of the mainstream smoke) is a technological solution with the longest application (Keith, 1978). In the middle of the last century, the addition of filters to the cigarettes resulted in a significant removal of harmful substances but smokers still considered tobacco smoke as "fine". Cigarette filters are specifically designed to absorb vapors and accumulate smoke particulate matter. They are constituted of cellulose acetate and even $95 \%$ of the world cigarette market is based on the cellulose acetate filters.

Filtration may remove up to $30 \%$ of the unwanted components of tobacco smoke. Further increase of filter efficiency can be improved by increasing filters ventilation (Srbinoska et al., 2014) or by selective filtration (Kassman, 1984) of tobacco smoke elements, making the combined filter. Filter efficiency (or filter retention) is the percentage of the incoming smoke components retained by a filter (Voges, 1984). Selective filtration means adding special materials (activated carbon, synthetic resins, zeolites) into the cellulose acetate filters. Specific smoke components may be retained in different relative amounts, depending of the nature of the components, the smoke and the filter material. Different materials may be placed in the cavities of composite filters in order to improve filter efficiency (Adnadjević and Nikolić, 1998; Morie et al., 1975; Duke, 1986; Scherer et al., 2006; Laugesen and Fowles, 2005; Agyei-Aye et al., 2004; Mola et al., 2008; Coggins and Gaworski, 2008; Winter et al., 2006).

Sorption capacity is the amount of sorbate taken up by the sorbent per unit mass (or volume) of the sorbent (Voges, 1984). Some studies have been carried out on using different sorbents to remove pollutants from cigarette smoke, For example, it has been proven that specially prepared composite aerogels, added in acetate filter, have a significant sorption capacity (Chai et al., 2020).

The addition of zeolites in cigarette filters represents one of novel technological solutions. The advantage of zeolites over other silicate-containing minerals, such as silica gel and clays, lies in its specific surface structure, which has excellent hydration, ion exchange and molecular screen capacities. Numerous studies showed that by using zeolites as filter materials, the quantities of harmful substances in the both condensate and gas phase were minimized. At the same time, only minor influence on the tobacco smoke aroma was observed (Bhatia, 1989; Kokotailo et al., 1978; Cvetković et al., 2000; 2002).

In the present study, the two types of zeolites, specified as Y and ZSM-5, with different degree of crystallinity, along with two modes of application (as a segment or as a powder added longitudinally with the filter fibers) were investigated in terms of estimating their filtration potentials.

\section{Materials and methods}

For the purposes of this study the zeolites were supplied from the Faculty of Physical Chemistry in Belgrade, where they were synthesized and chemically characterized. The main physico - chemical characteristics of the investigated zeolites are given in Table 1.

Table 1.

Physico-chemical characteristics of the investigated zeolites

\begin{tabular}{|l|l|l|}
\hline Parameter & Y & ZSM-5 \\
\hline Degree of crystallinity (\%) & 100 & 98 \\
\hline SiO2 content (mass \%) & 64.8 & 99.9 \\
\hline Al203 content $($ mass \%) & 22.9 & 0.01 \\
\hline Medium diameter of particles of crystals $(\mu \mathrm{m})$ & 1.2 & 1.2 \\
\hline Specific surface $(\mathrm{m} 2 / \mathrm{g})$ & 920 & 460 \\
\hline Specific pore volume $(\mathrm{cm} 3 / \mathrm{g})$ & 0.30 & 0.18 \\
\hline Degree of hydrophobicity (\%) & 0 & 100 \\
\hline Diameter channel $(\AA)$ & 8 & 6 \\
\hline Particle size $(\mu \mathrm{m})$ & $150-400$ & $150-400$ \\
\hline
\end{tabular}

Zeolites were activated and kept in a sealed glass jar until the moment of use.

1. Preparation of cigarette samples: A mixture of tobacco blend, the American type blend (Table 2), from the production of a Serbian cigarette factory has been used for the experiment.

Cigarettes were produced on the Protos 10 cigarette maker (Hauni, Germany). Basic characteristics of the cigarettes were as follows: length $84 \mathrm{~mm}$; weight $970 \mathrm{mg} \pm 0.5$; cigarette paper permeability $42 \mathrm{CU}$; filter length $20 \mathrm{~mm}$; acetat towel characteristics - 2.1Y / 42000. For the experiment, only the cigarettes weighing $970 \mathrm{mg} \pm 0.5$ were used.

2. Preparation of cigarettes with zeolites: Zeolites were added in the quantity of $60 \mathrm{mg}$ according to the mode of the application given in Table 3. Samples $\mathrm{Hl}$ and $\mathrm{Bl}$ were inflicted manually in powder form, using a polypropylene tube. Samples Hs and Bs were inflicted in the segment form. The first half of the filter was replaced with granulated zeolites with particle size $600-800 \mu \mathrm{m}$. The second half of pure cellulose acetate is in contact with the smoker's mouth.

Table 2.

The composition of a typical American blend (Davis and Nielsen, 1999)

\begin{tabular}{|l|l|}
\hline Tobacco & $\begin{array}{l}\text { Percentage } \\
\text { share }\end{array}$ \\
\hline Flue cured (FC) - Virginia & $25-35$ \\
\hline Air cured (AC) - Burley & $25-35$ \\
\hline Sun cured (SC) - Oriental tobacco & $3-15$ \\
\hline Expanded stem & $3-10$ \\
\hline RECON (Reconstituted tobacco) & $10-25$ \\
\hline Total & 100 \\
\hline
\end{tabular}


Table 3.

Designation of samples

\begin{tabular}{|l|l|l|l|}
\hline $\begin{array}{l}\text { Zeolite } \\
\text { type }\end{array}$ & $\begin{array}{l}\text { Zeolite } \\
\text { mark }\end{array}$ & $\begin{array}{l}\text { Mode of zeolite } \\
\text { application }\end{array}$ & $\begin{array}{l}\text { Sample } \\
\text { mark }\end{array}$ \\
\hline $\mathrm{Y}$ & $\mathrm{H}$ & longitudinally & $\mathrm{H}_{\mathrm{l}}$ \\
\cline { 3 - 4 } & & by segment & $\mathrm{H}_{\mathrm{s}}$ \\
\hline ZSM-5 & \multirow{2}{*}{$\mathrm{B}$} & longitudinally & $\mathrm{B}_{\mathrm{l}}$ \\
\cline { 3 - 4 } & & by segment & $\mathrm{B}_{\mathrm{s}}$ \\
\hline
\end{tabular}

3. Analysis of the solid phase of mainstream tobacco smoke: For the collecting of particulate matter (total particulate matter, TPM) cigarettes were smoked on the BORGWALDTH RM 20/CSR under the standard conditions: puffing $2 \mathrm{~s}$, smoldering $58 \mathrm{~s}$, butt length 23 $\mathrm{mm}$, puffing volume of $35 \mathrm{~mL}$. From each sample, 20 cigarettes were smoked. Before analysis, the cigarettes were conditioned during 48 hours in the conditioning chamber Borgwaldt (Heinr. Borgwaldt GmbH, Germany), at the temperature of $22 \pm 2^{\circ} \mathrm{C}$ and relative humidity of $60 \pm 5 \%$, according to ISO 3402 (1999).

The determination of TPM was acomlished according to ISO 4387 (2000). The smoke condensate was extracted from Cambridge filter using 2-propanol (GC purity, Sigma-Aldrich). The nicotine content of the total particulate matter was determined by gas chromatography according to ISO 10315 (2013). The water content of TPM was determined by gas chromatography according to ISO 10362-1 (1999). The tar content was determined by subtracting the water content and the nicotine content from TPM, according to ISO 4387. The ambient conditions for smoking were specified as in ISO 3308 (2012).

4. Analysis of the gas phase of mainstream tobacco smoke: The gas phase of the mainstream tobacco smoke was collected in the pre-vacuum packed bags, specialy designed for gas samples. The content of CO present in the vapour phase of the smoke was determined by NDIR analyzer according to ISO 8454 (2007).

In parallel with experimental samples with special filtration materials, the control sample $\emptyset$ was analyzed All analyses were conducted in triplicate. The values of different smoke parameters are represented as mean values.

For each sample, the data are as follows:

Degree of filter efficiency (Rx), or degree of relative decrease of certain components in cigarette smoke, which is calculated by the formula:

$$
\mathrm{Rx}=\frac{|\mathrm{Cxi}-\mathrm{Cxo}|}{\mathrm{Cxo}} \times 100
$$

Cxi - content of component $\mathrm{x}$ in mainstream cigarettes smoke with the composite filter,

Cxo - content of component $x$ in mainstream cigarettes smoke with cellulose acetate-filter.

Sorption capacity of cigarette filters (Kx), or the amount of nicotine, tar and CO absorbed (in grams) per unit mass of test material, which is calculated by the formula:

$$
\mathrm{Kx}=\frac{|\mathrm{Cxo}-\mathrm{Cxi}|}{\mathrm{m}} \times 100
$$

\section{Results and discussion}

Quantities of tar, nicotine and CO detected in the smoke of the control cigarette, as well as in the cigarettes made of composite filters with zeolites are presented in Table 4.

Based on the results shown in Table 4, it can be seen that the reduction of undesirable smoke components was at different level. The minimal effect of removing of the analyzed components of mainstream tobacco smoke was observed in $\mathrm{H}_{\mathrm{s}}$ sample where the zeolite was applied as a compact segment of the filter. In this case, the amount of nicotine in mainstream cigarette smoke was $0.53 \mathrm{mg} / \mathrm{cig}$, the amount of tar was $10.16 \mathrm{mg} / \mathrm{cig}$ and the amount of CO was 9.10 $\mathrm{mg} / \mathrm{cig}$. Some similar amounts for the investigated parameters were found in the sample $B_{s}$. When the zeolites were applied longitudinally, the maximal removal of nicotine, tar and CO content was found in the sample $\mathrm{H}_{1}$ (the amount of nicotine was $0.35 \mathrm{mg} / \mathrm{cig}$, the tar was $3.44 \mathrm{mg} / \mathrm{cig}$ and CO was only $1.39 \mathrm{mg} / \mathrm{cig}$ ). In general, the segmented zeolites were less efficient than those which were longitudinally applied. Both modes of zeolite application showed very good removing capacity in regard to the three investigated parameters and the only exception was in the case of zeolite $\mathrm{B}$ ı regarding nicotine.

Table 4.

Amounts of nicotine, tar and $\mathrm{CO}$ in mainstream cigarette smoke

\begin{tabular}{|l|l|l|l|l|}
\hline Sample & $\begin{array}{l}\text { Weight } \\
\text { of added } \\
\text { zeolite } \\
(\mathrm{mg})\end{array}$ & $\begin{array}{l}\text { Nicotine } \\
(\mathrm{mg} / \mathrm{cig})\end{array}$ & $\begin{array}{l}\text { Tar } \\
\text { (mg/cig) }\end{array}$ & $\begin{array}{l}\text { CO } \\
\text { (mg/cig) }\end{array}$ \\
\hline$\varnothing$ & $/$ & 0.85 & 10.38 & 10.10 \\
\hline $\mathrm{H}_{\mathrm{s}}$ & 60 & 0.53 & 10.16 & 9.10 \\
\hline $\mathrm{B}_{\mathrm{s}}$ & 60 & 0.45 & 8.52 & 8.90 \\
\hline $\mathrm{H}_{\mathrm{l}}$ & 60 & 0.35 & 3.44 & 1.39 \\
\hline $\mathrm{B}_{\mathrm{l}}$ & 60 & 0.73 & 4.88 & 7.28 \\
\hline
\end{tabular}

From the calculated degree of filter efficiency $\left(\mathrm{R}_{\mathrm{x}}\right)$, presented in Table 5, it could be concluded that degree of reduction for each investigated compound $\left(\mathrm{R}_{\mathrm{n}}, \mathrm{R}_{\mathrm{t}}\right.$, $\mathrm{R}_{\mathrm{co}}$ ) was predominantly affected by the type of zeolite, with the notification that both zeolite types have better efficiency if added longitudinally with filter fibers.

Table 5.

Degree of filter efficiency in nicotine, tar and CO removing from mainstream tobacco smoke

\begin{tabular}{|l|l|l|l|}
\hline Sample & $\mathrm{R}_{\mathbf{n}}(\%)$ & $\mathrm{R}_{\mathbf{t}}(\%)$ & $\mathrm{R}_{\mathrm{co}}(\%)$ \\
\hline $\mathrm{H}_{\mathrm{s}}$ & 37.64 & 2.12 & 9.90 \\
\hline $\mathrm{H}_{\mathrm{l}}$ & 58.82 & 66.86 & 86.24 \\
\hline $\mathrm{B}_{\mathrm{s}}$ & 47.06 & 17.92 & 11.88 \\
\hline $\mathrm{B}_{\mathrm{l}}$ & 14.11 & 52.98 & 27.92 \\
\hline
\end{tabular}

$R_{n}$ - degree of filter efficiency for nicotine; $R_{t}$ - degree of filter efficiency for tar; Rco - degree of filter efficiency for $\mathrm{CO}$

Sample $\mathrm{H}_{1}$ showed higher filter efficiency for nicotine (58.82\%), tar (66.86\%) and CO (86.24\%) in comparison with the sample $\mathrm{H}_{\mathrm{s}}$. Sample $\mathrm{B}_{\mathrm{l}}$ had higher filter efficiency for tar $(52.98 \%)$ and CO $(27.92 \%)$ than the sample $B_{s}$, while the sample $B_{s}$ had higher filter efficiency for nicotine (14.11\%).

The influence of the type and mode of application on the degree of reduction of the compounds from the

m - mass of added zeolite. 
particulate matter is also clearly illustrated by the calculated quantities of sorbed nicotine, tar and CO per unit of zeolite mass. Sorption capacity of experimental cigarette filters $\left(\mathrm{K}_{\mathrm{x}}\right)$ are presented in Table 6 .

Sample $\mathrm{H}_{1}$ showed higher sorption capacity for nicotine $(0.84 \%)$, tar $(11.57 \%)$ and CO $(14.52 \%)$ in comparison with the sample $\mathrm{H}_{\mathrm{s}}$. Sample $\mathrm{B}$ l had higher sorption capacity for tar $(9.17 \%)$ and CO $(4.70 \%)$ than the sample $B_{s}$, while the sample $B_{s}$ had higher sorption capacity for nicotine $(0.67 \%)$.

Table 6.

The sorption capacity of cigarette filters

\begin{tabular}{|l|l|l|l|}
\hline Sample & $\mathrm{K}_{\mathrm{n}}(\%)$ & $\mathrm{K}_{\mathrm{t}}(\%)$ & $\mathrm{K}_{\mathrm{CO}}(\%)$ \\
\hline $\mathrm{H}_{\mathrm{s}}$ & 0.54 & 0.37 & 1.67 \\
\hline $\mathrm{H}_{\mathrm{l}}$ & 0.84 & 11.57 & 14.52 \\
\hline $\mathrm{B}_{\mathrm{s}}$ & 0.67 & 3.10 & 2.00 \\
\hline $\mathrm{B}_{\mathrm{l}}$ & 0.20 & 9.17 & 4.70 \\
\hline
\end{tabular}

$\mathrm{K}_{\mathrm{n}}$ - the sorption capacity for nicotine; $\mathrm{K}_{\mathrm{t}}$ - the sorption capacity for tar; $\mathrm{K}_{\mathrm{Co}}$ - the sorption capacity for $\mathrm{CO}$
The comparison of filters efficiency and sorption capacity of cigarette filters for the same zeolite type applied in different ways was done on the basis of the data presented in Tables 5 and 6 . The ratios are graphically presented in Figure 1.

Namely, it was obvious that the sample $\mathrm{H}_{1}$ was more efficient than sample $\mathrm{H}_{\mathrm{s}}$ (approximately 1.56 times for nicotine, 31.53 times for tar and 8.72 times for C0). Degree of filter efficiency in the sample $\mathrm{B}_{1}$ was 2.96 times higher for tar and 2.35 times for CO than in the sample $B_{s}$, whereas degree of filter efficiency for nicotine was much higher in the sample $B_{s}(3.34$ times higher than in $\mathrm{Bl}_{1}$ ).

The obtained results suggest that the samples in which the filtration material was applied longitudinally on the acetate-cellulose filter, have higher efficiency in comparison with the samples where the same material was applied in the form of segments.

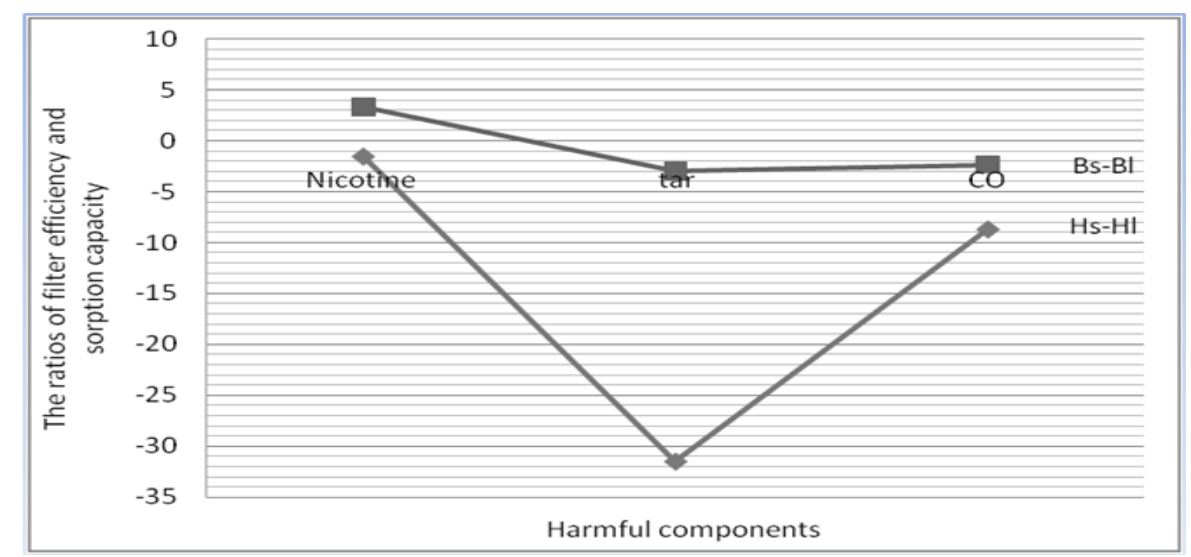

Figure 1. The comparison of filters efficiency and sorption capacity between the same types of zeolites

Namely, the application of zeolites in the form of segments can led to blocking effects. Factually, the layer of zeolite, which came first into the contact with tobacco smoke, may become oversaturated with smoke particles. These particles may plug zeolite pores which in further may limit the absorbtion activity of other zeolite layers and the smoke can not pass so easily. The main pore blocker is most probably tar, because its adhesive abilities are known as significant. According to the definition tar is a brown and sticky mass of smoke particles collected on the filter during machine smoking (Voges, 1984).

The degree of plugging depends on the diameter of the channel as well as on the level of hydrophobicity of the material. For materials with smaller diameter channels, plugging is easier. Of the samples that were used, the channels of ZSM- 5 type of zeolite (samples B) have smaller diameter, $6 \AA \AA$, than $Y$ type of zeolite (samples H), 8Å. However, the strength of zeolite active site also depends on the $\mathrm{Si} / \mathrm{Al}$ relationship, wherein a direct correlation was observed (Breck 1974; Catlow 1992). In the opposite to the zeolite $B$, the zeolite $H$ is hydrophilic (Table 1) and - particle agglutination and pore closing occure easier making sample $\mathrm{H}_{s}$ less efficient than the sample $\mathrm{B}_{\mathrm{s}}$. However, when zeolites were applied longitudinally, tobacco smoke made a better contact with the zeolite particles, thus the zeolite could fully activate its sorption capacity.

\section{Conclusion}

The results of this experiment showed that both investigated zeolites, regardless of their types or mode of their application are very efficient in the reduction of hazardous substances in mainstream cigarette smoke. The type of zeolite with greater channel diameter, i.e. zeolite Y, showed a better efficiency than zeolite ZSM-5.

The substantial role in the removal of the tested parameters of mainstream tobacco smoke lies in the method of the zeolite application on the filter, i.e. in the longitudinal application. This method leads to a better contact between the particulate matter of tobacco smoke and the zeolite particle. When the zeolites were applied as a segment in the filters, the blocking effect was observed.

The obtained results are of great importance since the purification of tobacco smoke contributes significantly to the public health enhancement, as well as to the reduction of air pollution, which originate from environmental tobacco smoke (ETS). Further research will be focused to the use of zeolites with larger diameter channels, applied longitudinally to the filter. 


\section{Acknowledgments}

Authors are grateful to the Ministry of Education, Science and Technology Development of the Republic of Serbia for their support (Project No. 46010) and to Professor Borivoj Adnadjevic for supplying the zeolite materials.

\section{References}

Adnadjević, B., Nikolić, M. (1998). New filtration materials for nicotine, tar and carbon monoxide reduction in cigarette smoke. III Yugoslav Symposium of Food Technology, Proccesing III, Faculty of Agriculture, Belgrade, Serbia, 63-67.

Agyei-Aye, K., Appleton, S., Rogers, R.A., Taylor, C.R. (2004). Assessment of the elution of charcoal, cellulose acetate, and other particles from cigarettes with charcoal and activated charcoal/resin filters. Inhalation Toxicology, 16, 615-635.

Bhatia, S. (1989). Zeolite Catalysis: Principles and Applications. CRC Press Taylor and Francis Group, Boca Raton, London, New York.

Breck, D.V. (1974). Zeolite Molecular Sieves. John Wiley \& Sons, New York.

Catlow, C.R.A. (1992). Modelling of Structure and Reactivity in Zeolites. Academic Press, London.

Chai, S., Dai, X., Wu, T., Liu, B., Yao, H., Yua,n Y., Wu, Q. (2020). Synthesis of $\mathrm{Si} / \mathrm{O} / \mathrm{C} / \mathrm{N}$ quaternary composite aerogels with micro/mesoporous structures and their selective adsorption property for volatile carbonyl compounds in cigarette smoke. Microporous and Mesoporous Materials, 301, 110164.

Coggins, C.R., Gaworski, C.L. (2008). Could charcoal filtration of cigarette smoke reduce smoking-induced disease? A review of the literature. Regulatory Toxicology and Pharmacology, 50(3), 359-365.

Cvetković, N., Adnadjević, B., Nikolić, M. (2000). Carbon monoxide elimination from tobacco smoke. CORESTA Congress, Spec. Edition, Lisbon, Portugal, 214 pp.

Cvetković, N., Adnadjević, B., Nikolić, M. (2002). Catalytic reduction of $\mathrm{NO}$ and NOx content in tobacco smoke. Beiträge zur Tabakforschung International, 20, 43-48.

Davis, D., Nielsen, M.T. (1999). Tobacco - Production, Chemistry and Technology. Blackwell Science, Oxford, United Kingdom.

Djulančić, N., Radojičić, V., Srbinoska, M. (2013). The Influence of Tobacco Blend Composition on the Carbon Monoxide Formation in Mainstream Cigarette Smoke. Archives of Industrial Hygiene and Toxicology, 64(1), 107-113.

Duke, M.G. (1986). Predicting the efficiency of cigarette filters. Filtration and Separation, 23(6), 358-362.

Fawky, A. (2004). Cigarette Product Development. Tobacco Reporter/Speccomm International, Raleigh, NC, USA.

Hoffmann D., Tso T.C., Gori G.B. (1980). The less harmful cigarette. Preventive Medicine, 9(2), 287-296.

Hoffman, D., Hoffman, I. (1997). The changing cigarette. Journal of Toxicology and Environment Health, 50, 30764.

Institute of Medicine (2001). Clearing the smoke. Assessing the science base for tobacco harm reduction. Stratton, K. et al. (Eds.). National Academy Press, Washington, USA.

International Agency for Research on Cancer - IARC (2004). Tobacco smoke and involuntary smoking. Monographs on the evaluation of carcinogenic risks to humans. IARC Monograph, Lyon, France, 1191-1413 pp.

ISO Standard 3402 (1999). Tobacco and Tobacco Products Atmosphere for Conditioning and Testing.

ISO Standard 4387 (2000). Cigarettes - Determination of Total and Nicotine-Free Dry Particulate Matter Using a Routine Analytical Smoking Machine.

ISO 10315 (2013). Cigarettes-Determination of nicotine in smoke condensates - Gas-chromatographic method.
ISO 10362-1 (1999). Cigarettes - Determination of water in smoke condensates - Part 1: Gas-chromatographic method.

ISO 3308 (2012). Routine Analytical Cigarette-Smoking Machine - Definitions and Standard Conditions.

ISO 8454 (2007). Cigarettes - Determination of carbon monoxide in the vapour phase of cigarette smoke - NDIR method.

Kassman, A.J. (1984). Design of the Filter System. Recent Advancei Tobacco Science, 10, 72-87.

Keith, C.H. (1978). Physical mechanisms of smoke filtration. Recent Advancei Tobacco Science, 4, 25-45.

Kokotailo, G.V., Lawton, S.L., Olson, D.H., Meier, W.M. (1978). Structure of synthetic zeolite ZSM-5. Nature, 272(5652), 437-438.

Laugesen, M., Fowles, J. (2005). Scope for regulation of cigarette smoke toxicity: the case for including charcoal filters. New Zealand Medical Journal, 118(1213), U1402.

Mola, M., Hallum, M., Branton, P. (2008). The characterization and evaluation of activated carbon in a cigarette filter. Adsorption, 14(2-3), 335-341.

Morie, G.P., Sloan, C.H., Baggett, M.S. (1975). Parameters affecting the selective filtration of certain tobacco smoke components. Beiträge zur Tabakforschung International, 8(3), 145-9.

Bethesda, Maryland, USA, NIH Publication No 96-4028.

Radojičić, V., Nikolić, M., Adnađević, B. (2005). CO Reduction in Cigarette Smoke by Application of Purposely Sintetise Zeolite Catalyst. Environmental Protection of Urban and Suburban Settlements, Monograph, Novi Sad, Serbia, 3337 pp.

Radojičić, V., Nikolić, M, Adnađević, B. (2006). Possibility of cigarette management by modeling pyrolysis process. 9 th International Conference DQM, Quality and Reliability Management Research Center, Prijevor, Serbia, 355-361.

Radojičić, V., Nikolić, M. (2006). Efficiency of measures for environmental protection of tobacco smoke. Ecological Truth, Ecoist '06, Technical faculty, Bor, Serbia, 100-104.

Radojičić, V., Nikolić M. (2007). Development of new technological proceeding for decrease of TAR and CO production in tobacco smoke. Ecological Truth, Ecoist '07, Technical faculty, Bor, Serbia, 144-148.

Radojičić, V., Nikolić, M., Srbinoska, M. (2008). Influence of zeolite type and quantity added directly to cigarette blend to the changes of SBR and TAR content in tobacco smoke. Tutun/Tobacco, 58 (1-12), 87-95.

Radojičić, V., Nikolić, M., Adnađević, B. (2009a). The influence of zeolite type added to the cigarette blend on the changes of pyrolitic temperatures. Hemijska Industrija, 63(5A), 579-583.

Radojičić, V., Nikolić, M., Srbinoska, M. (2009b). Influence of the type of silicate materials in reduction of the harmful compounds in solid phase of tobacco smoke. Tutun/Tobacco, 59(9-10), 234-241.

Rodgman, A., Green, C.R. (2003). Toxic chemicals in cigarette mainstream smoke - hazard and hoopla. Beiträge zur Tabakforschung International, 20(8), 481-545.

Rodgman, A., Perfetti, T.A. (2009). The chemical components of tobacco and tobacco smoke. CRC Press Taylor and Francis Group, Boca Raton, London, New York.

Scherer, G., Urban, M., Engl J., Hagedorn, H.W., Riedel K. (2006). Influence of smoking charcoal filter tipped cigarettes on various biomarkers of exposure. Inhalation Toxicology, 18, 821-829.

Srbinoska, M., Kirkova, S., Radojičić, V., Đulančić, N. (2014). Compariso of Tar, nicotine and carbon monoxide from slim cigarettes with different degree of filter vents blocking. International Conference, 70 years of Tobacco and Tobacco Products Institute, Plovdiv, Bulgaria, CD version, 6 pages.

Tobacco Law of the Republic of Serbia, ("Fig. Gazette" No., $101 / 2005$, 90/2007, 95/2010, 36/2011, 6/2012... 91/2019).

US Federal Trade Commission (2000). Tar, Nicotine, and Carbon Monoxide of the Smoke of 1294 Varieties of Domestic Cigarettes for the Year 1998. Washington, DC, 2000. 
Voges, E. (1984). Tobacco Encyclopedia. Tobacco Journal International, Germany.

Winter, D., Cashmore M., Coleman M., Errington G., White P. (2006). The application of a two level factorial design to the selective reduction of phenolic compounds in mainstream smoke using cellulose acetate filters. CORESTA Joint Meeting of the Smoke Science and Product Technology Study Groups, Paris, France.

World Health Organization (2000). Final Report: Advancing knowledge on regulating tobacco products, Oslo, Norway. 